\title{
PEMANFAATAN CHITOSAN DARI LIMBAH UDANG GALAH SEBAGAI EDIBLE COATING BUAH TOMAT DENGAN VARIASI WAKTU PENYIMPANAN
}

\section{Utilization of Chitosan from Waste Giant Prawns as Edible Coating Tomato Fruit with Long Variation of Storage}

\author{
Nenengsih Verawati ${ }^{1 *}$, Nur Aida ${ }^{2}$, Khairul Muttaqin ${ }^{2}$ \\ 1) Jurusan Teknologi Hasil Pengolahan, Politeknik Negeri Ketapang \\ Jl. Rangga-Sentap Dalong Sukaharja, Kabupaten Ketapang \\ 2) Jurusan Teknik Sipil, Politeknik Negeri Ketapang \\ Jl. Rangga-Sentap Dalong Sukaharja, Kabupaten Ketapang \\ *Penulis Korespondensi, email: nenengverawati6@gmail.com
}

\begin{abstract}
ABSTRAK
Limbah kulit dan kepala udang mengandung senyawa kitin yang bermanfaat dalam bidang pangan. Sintesis kitin menjadi chitosan dapat bermanfaat sebagai edible coating pada buah tomat. Tujuan dari penelitian ini untuk mengetahui kadar air, abu dan protein pada chitosan cangkang udang galah dan mengetahui pengaruh penambahan chitosan terhadap lama penyimpanan buah tomat. Analisis data dalam penelitian menggunakan Rancang Acak Kelompok (RAK) dua faktor yaitu lama penyimpanan tomat dengan 5 taraf, yaitu $0 ; 3 ; 6$; 9 ; dan 12 hari, dan konsentrasi serbuk chitosan dengan 4 taraf, yaitu $0 \%$; $1 \% ; 1.5 \%$ dan $2 \%$. Hasil analisis chitosan yaitu kadar air $7.90 \%$; abu $3.72 \%$ dan protein $4.01 \%$. Penambahan konsentrasi chitosan memberikan pengaruh terhadap jumlah dissolved solids, susut berat, total acidity dan vitamin $\mathrm{C}$ selama penyimpanan buah tomat.
\end{abstract}

Kata Kunci: Chitosan, Waktu penyimpanan, Tomat

\section{ABSTRACT}

Shrimp skin and head waste is containing chitin compounds that are useful in the food sector. Chitin synthesis into chitosan can be useful as an edible coating on tomatoes. The purpose of this study was to determine the water content, ash and protein in chitosan shells of giant prawns and determine the effect of chitosan on the storage time of tomatoes. Data analysis in the study used two factor Randomized Block Design (RAK), namely storage time of tomato with 5 level, 0; 3; 6; 9; and 12 days, and chitosan powder concentration with 4 levels, $0 \% ; 1 \% ; 1.5 \%$ and $2 \%$. Chitosan analysis results obtained for $7.90 \%$ water content; ash $3.72 \%$ and protein $4.01 \%$. Addition of chitosan concentration has an effect on total dissolved solids, weight loss, total acid and vitamin $C$ during storage of tomatoes.

Keywords: Chitosan, Storage time, Tomato

\section{PENDAHULUAN}

Kalimantan Barat merupakan daerah yang dikelilingi oleh beberapa sungai dan rawarawa yang menjadi sumber perikanan khususnya udang. Salah satu udang air tawar yang menjadi keunggulan adalah udang galah (Macrobrachium rosenbergii) yang memiliki nilai ekonomis tinggi. Udang galah banyak dibudidayakan oleh masyarakat karena mudah dalam pemeliharaan serta tahan terhadap berbagai penyakit. Udang galah diperoleh dari beberapa sungai yang terdapat di Kabupaten Ketapang yaitu Sungai Pawan. Pemanfaatan limbah hasil perikanan menjadi chitosan diharapkan bisa menjadi alternatif pengolahan limbah dalam menghasilkan produk baru sehingga mengurangi pencemaran dan aroma sehingga meningkatkan estetika lingkungan yang baik (Mursida, 2018). 
Sebanyak $50 \%$ dari limbah udang mengandung kitin yang terdapat pada kepala, kulit dan ekor dari udang (widodo, 2005). Selain itu, menurut Rachmania (2011) kandungan kitin, chitosan dan turunannya juga banyak ditemukan pada limbah udang. Chitosan dapat bermanfaat dalam bidang obat-obatan, farmasi, kedokteran, kesehatan, pengolahan limbah dan bidang pangan. Pada industri pengolahan hasil perikanan khususnya udang dan rajungan menghasilkan limbah kulit atau cangkang yang mengandung polimer kitin yang digunakan dalam pembuatan chitosan. Untuk mendapatkan $15-20 \%$ chitosan diperlukan kitin $60-70 \%$ dari limbah kepala udang (Linawati, 2006). Pada bidang pangan, chitosan bermanfaat sebagai edible coating.

Buah yang diberi lapisan tipis dengan tujuan untuk menghambat keluarnya gas, uap air, dan menghindari kontak dengan oksigen sehingga memperlambat proses pemasakan dan pencoklatan buah, disebut dengan edible coating. Buah yang telah dilapisi bersifat aman walaupun dikonsumsi langsung. Limbah kulit udang-udangan (Crustaceae, kepiting dan Kepiting/Crab) mengandung polisakarida yang merupakan bahan pembuatan chitosan dan berfungsi sebagai coating buah. Aplikasi chitosan sebagai pelapis dapat memperpanjang umur simpan buah tomat dan leci (Trisnawati, 2013). Widodo dan Zulferiyenni (2008), menyatakan bahwa penggunaan active packaging dengan tambahan perlakuan pelapisan duku dan chitosan mampu memperlambat proses pencoklatan kulit buah. Konsentrasi chitosan $0.5 \%$ dan $1 \%$ dapat memperpanjang penyimpanan buah salak hingga 15 hari (Rachmawati, 2010). Hardjito (2006) menyatakan bahwa chitosan konsentrasi $1.5 \%$ dapat menghambat kerusakan buah stroberi yang disimpan pada suhu $13^{\circ} \mathrm{C}$.

Proses fisiologis respirasi dan transpirasi akan terus berlangsung setelah buah dipanen sehingga perlu penanganan yang tepat. Salah satunya tomat yang merupakan buah klimaterik yang bersifat mudah rusak, namun memiliki pasar yang terbuka dan cukup luas baik pasar lokal maupun ekspor (Rusmanto, 2017). Kerusakan fisik dan mekanis selama pasca panen menjadi permasalahan utama khususnya petani tomat dan pedagang. Sehingga dibutuhkan metode yang tepat untuk penanganan pasca panen yaitu salah satunya dengan penggunaan bahan pelapis (edible coating) dari chitosan.

\section{BAHAN DAN METODE}

\section{Bahan}

Bahan yang digunakan pada penelitian ini yaitu limbah kulit udang galah yang diperoleh dari Pasar Haji Sani, Ketapang, Kalimantan Barat. Bahan lainnya yaitu: tomat diperoleh dari petani Desa Sukarja, Ketapang, Kalimantan Barat, $\mathrm{HCl}$, Aquades, $\mathrm{NaOH}$, kertas $\mathrm{pH}$ dan $\mathrm{CH}_{3} \mathrm{COOH}$.

\section{Alat}

Oven, desikator, timbangan, ayakan berukuran 80 mesh, gelas kimia, dan waterbath merupakan alat-alat yang digunakan dalam penelitian.

\section{Desain Penelitian}

Penelitian pemanfaatan chitosan dari limbah kulit udang galah sebagai edible coating pada tomat dengan variasi lama penyimpanan terdiri faktor lama penyimpanan dan konsentrasi chitosan. Lama penyimpanan terdiri dari penyimpanan 0 hari $(\mathrm{H} 0), 3$ hari $(\mathrm{H} 3), \mathrm{p}$ 6 hari $(\mathrm{H} 6), 9$ hari $(\mathrm{H} 9)$ dan 12 hari $(\mathrm{H} 12)$. Konsentrasi chitosan terdiri dari chitosan $0 \%(\mathrm{~K} 1)$, chitosan $1 \%$ (K2), chitosan $1.5 \%$ (K3), chitosan $2 \%(\mathrm{~K} 4)$.

\section{Tahapan Penelitian}

\section{Pembuatan Tepung Kulit Udang}

Untuk membuat tepung kulit udang, sebanyak $3 \mathrm{~kg}$ limbah kulit udang galah direbus selama 15 menit. Setelah direbus, dicuci dengan air sampai bersih, pengeringan menggunakan cabinet dryer suhu $80^{\circ} \mathrm{C}$ dalam waktu 48 jam. Kulit udang yang sudah kering, ditimbang, pengecilan ukuran dan diayak menggunakan ayakan ukuran 80 mesh. 
Sebelum dilakukan proses pembuatan chitosan, terlebih dahulu ditetapkan kadar air, abu dan proteinnya (Agustina, 2015).

\section{Pengurangan kadar mineral}

Proses pengurangan kadar mineral diawali dengan $200 \mathrm{~g}$ tepung kulit udang yang sudah halus dimasukkan ke dalam erlenmeyer, dilarutkan dengan $\mathrm{HCl} 1.5 \mathrm{M}(1: 15 \mathrm{~b} / \mathrm{v})$, pemanasan suhu $60-70^{\circ} \mathrm{C}, 240$ menit dalam waterbath shaker berkecepatan $50 \mathrm{rpm}$. Padatan yang telah dihasilkan dicuci menggunakan aquades sampai $\mathrm{pH}$ padatan tidak berubah. Padatan dimasukkan ke oven suhu $80^{\circ} \mathrm{C}$ dalam sehari sehingga kering.

\section{Pengurangan kadar protein}

Serbuk yang telah melalui proses pengurangan mineral, dilarutkan dengan natrium hidroksida $3.5 \%(1: 10 \mathrm{~b} / \mathrm{v})$, dipanaskan pada suhu $60-70^{\circ} \mathrm{C} \pm 240$ menit dalam waterbath shaker berkecepatan $50 \mathrm{rpm}$. Padatan yang telah dihasilkan, dicuci menggunakan aquades sampai $\mathrm{pH}$ padatan tidak berubah. Padatan dimasukkan ke oven suhu $80^{\circ} \mathrm{C}$ dalam sehari hingga kering. Serbuk yang kering didinginkan menggunakan desikator dan dilanjutkan penimbangan. Padatan tersebut diidentifikasi secara kualitatif apakah mengandung kitin dengan mendeteksi reaksi warna Van Wesslink dan metode Knorr. Deteksi reaksi warna Van Wesslink ditunjukkan dengan perubahan warna coklat oleh $\mathrm{I}_{2}$ dan $\mathrm{KI}$ menjadi violet oleh $\mathrm{CH}_{3} \mathrm{COOH}$. Menurut Khan et al., (2002) dalam Agustina (2015), metode Knorr merupakan metode yang digunakan untuk sistesis chitosan melalui pelepasan gugus asetil pada molekul kitin dengan menambahkan 60\% natrium hidroksida pada serbuk yang telah dilakukan pengurangan kadar protein, dipanaskan suhu $100-110^{\circ} \mathrm{C} \pm 240$ menit dalam waterbath shaker berkecepatan $50 \mathrm{rpm}$. Padatan yang telah dihasilkan, dicuci menggunakan aquades sampai pH padatan tidak berubah. Padatan dimasukkan ke oven suhu $80^{\circ} \mathrm{C}$ dalam sehari sehingga menjadi chitosan kemudian dikarakteristik secara kualitatif menggunakan larutan ninhidrine.

\section{Aplikasi chitosan}

Chitosan dengan konsentrasi yang bervariasi yaitu $1 \%, 1.5 \%, 2 \% \mathrm{w} / \mathrm{v}$ kemudian ditempatkan masing-masing ke dalam gelas baker. Tomat yang telah disiapkan dicelupkan ke dalam larutan chitosan pada setiap gelas beker tersebut selama 60 menit, tomat diangin-anginkan pada suhu ruang. Tomat yang sudah dikeringkan, kemudian disimpan untuk dilakukan analisis jumlah soluble solids, susut berat, vitamin $\mathrm{C}$ (metode iodin), total acidity (metode titrasi) pada penyimpanan $0 ; 3 ; 6 ; 9$ dan 12 hari pada suhu kamar.

\section{Metode}

Data dari hasil analisis diuji Anova program SPSS 16, melalui metode RAK dengan 2 faktor yaitu waktu penyimpanan dan konsentrasi chitosan.

\section{Prosedur Analisis}

Adapun tahap penelitian dibagi menjadi 3 bagian yaitu pembuatan serbuk kulit udang, proses pengurangan mineral, pengurangan protein dan pengurangan gugus asetil, serta aplikasi chitosan sebagai edible coating pada tomat. Untuk mengetahui pengaruh chitosan terhadap lama penyimpanan buah tomat dilakukan dengan menggunakan aplikasi SPSS 16 dengan uji RAK 2 faktor. Faktor 1 adalah lama penyimpanan dengan 5 taraf yaitu $0 ; 3 ; 6 ; 9$ dan 12 hari. Faktor 2 yaitu konsentrasi serbuk chitosan dengan 4 taraf yaitu 0\%; 1\%; 1.5\% dan $2 \%$. Tujuan analisis tersebut adalah untuk mengetahui apakah waktu penyimpanan dan konsentrasi chitosan berbeda nyata pada taraf $5 \%$ terhadap hasil pengamatan susut berat, jumlah soluble solids, total acidity, dan Vitamin C. Parameter yang diamati untuk mengetahui pengaruh penambahan chitosan dengan waktu penyimpanan tomat adalah terdiri dari susut berat, jumlah soluble solids, total acidity, dan Vitamin C. 


\section{HASIL DAN PEMBAHASAN}

\section{Kadar Air, Abu dan Protein Serbuk Limbah Kulit Udang Galah}

Limbah kulit udang galah diperoleh dari beberapa rumah makan sebanyak $3 \mathrm{~kg}$, dikering suhu $80{ }^{\circ} \mathrm{C}$ selama 24 jam. Limbah kulit udang galah yang kering kemudian dihaluskan dan diayak dengan ukuran 80 mesh. Serbuk yang telah halus dianalisis kadar air, protein dan kadar abu. Hasil analisis kadar air, abu dan protein serbuk limbah kulit udang galah dapat dilihat pada Tabel 1.

Tabel 1. Komposisi kadar air, kadar abu dan protein serbuk limbah kulit udang galah

\begin{tabular}{|c|c|}
\hline Komposisi & (\%) \\
\hline $\begin{array}{l}\text { Air } \\
\text { Abu } \\
\text { Protein }\end{array}$ & $\begin{array}{c}9.11 \\
61.51 \\
12.21\end{array}$ \\
\hline
\end{tabular}

Hasil analisis menunjukan kadar abu lebih tinggi dari kadar protein dan kadar air, hal ini dikarenakan tingginya kandungan mineral dari kulit udang galah yang digunakan sebagai sampel dalam pembuatan chitosan. Hal tersebut sesuai dengan pernyataan Ploydee dan Chaiyanan (2014) dalam penelitian Nadia et al. (2018), bahwa kemungkinan habitat dan lingkungan tempat udang hidup menyebabkan perbedaan pada jumlah kadar abu.

Pembuatan chitosan melalui beberapa tahap yaitu, deproteinase, dimineralisasi dan deasetilasi (Nadia, 2014). Bahan baku sebanyak $900 \mathrm{~g}$ diperoleh rendemen chitosan 162.02 $\mathrm{g}$ atau sebanyak $18 \%$ dari bahan limbah kulit udang galah. Hal tersebut tidak berbeda jauh dengan hasil yang diperoleh Islama et al. (2011), dimana rendemen chitosan berkisar antara $15-21 \%$. Rendahnya rendemen yang dihasilkan disebabkan pada proses deproteinase, dimineralisasi dan deasetilasi banyak kitin yang hilang oleh pelarut, juga disebabkan oleh hilangnya selama pencucian. Waktu pemanasan yang berbeda pada waktu demineralisasi memberikan pengaruh pada rendemen yang diperoleh (Rochima, 2007). Penggunaan suhu pemanasan yang berbeda yaitu $90^{\circ} \mathrm{C}$ dan $70^{\circ} \mathrm{C}$ pada larutan asam klorida $1 \mathrm{~N}$ selama 1 jam menyebabkan reaksi antara kalsium, protein, lemak, fosfor, magnesium dan besi dengan asam klorida yang larut dalam air dan terbuang selama proses demineralisasi (Bastaman, 1989 dalam Rochima, 2007).

\section{Karakteristik Chitosan} berikut.

Tabel 2 menunjukkan mutu chitosan hasil analisis air, abu dan protein sebagai Tabel 2. Mutu Chitosan

\begin{tabular}{|c|c|}
\hline Komposisi & Nilai Chitosan \\
\hline $\begin{array}{l}\text { Air } \\
\text { Abu } \\
\text { Protein } \\
\text { Kelarutan } \\
\text { Ukuran } \\
\text { Corak }\end{array}$ & $\begin{array}{l}7.90 \% \\
3.72 \% \\
4.01 \% \\
\text { Larut } \\
\text { Serbuk } \\
\text { Kuning }\end{array}$ \\
\hline
\end{tabular}

Hasil karakterisasi chitosan diperoleh kadar air 7.90\%, lebih rendah dari chitosan komersial yaitu $\leq 10 \%$ (Nadia, 2018). Kadar air yang rendah pada chitosan dipengaruhi oleh suhu pengeringan $80^{\circ} \mathrm{C}$ selama 24 jam. Proses pengeringan yang baik pada saat pembuatan chitosan memberikan kadar air yang rendah untuk chitosan (Suptijah et al, 2011). Proses pengeringan, waktu pengeringan, banyak chitosan yang dikeringkan, luas tempat pengeringan dan metode pengeringan yang digunakan menentukan tinggi rendahnya kadar air pada chitosan (Hossain and lqbal, 2014; Rahmawati, 2012). Kadar air juga dipengaruhi 
konsentrasi $\mathrm{NaOH}$ dan ukuran partikel. Suharjo dan Harini (2005) menyatakan bahwa konsentrasi $\mathrm{NaOH}$ 50\% menunjukkan kadar air chitosan paling tinggi dibandingkan dengan konsentrasi $\mathrm{NaOH} 30 \%$ dan $40 \%$. Chitosan dengan kualitas yang baik dilihat dari tingginya jumlah air, jumlah air ditentukan oleh gugus asetil pada kitin yang tereduksi sehingga gugus asetil yang terlepas dari polimer kitin menjadi meningkat (Suharjo dan Harini, 2005).

Jumlah mineral yang terkandung dalam chitosan pada kulit udang galah diukur berdasarkan kandungan abu. Kulit udang galang sebesar $3.72 \%$ lebih tinggi dari kadar abu standar chitosan komersial yaitu $\leq 2 \%$ (Nadia, 2018). Kualitas air pada proses penetralan chitosan dan efektivitas proses dimineralisasi memengaruhi kadar abu pada chitosan (Suptijah, 2011). pH netral pada saat pencucian menentukan banyaknya kadar abu pada chitosan (Rahmawati, 2012).

Chitosan bersifat mudah berinteraksi dengan gugus amin $\left(\mathrm{NH}_{2}\right)$, apabila chitosan tersebut mengandung nitrogen. Chitosan akan memiliki reaktifitas yang tinggi, dapat menyerap air serta terlarut dalam larutan $\mathrm{CH}_{3} \mathrm{COOH}$ apabila terdapat $\mathrm{NH}_{2}$ (Kumari et al., 2016). Kadar nitrogen yang diperoleh pada kulit udang galah sebesar $4.1 \%$ masih belum memenuhi standar mutu chitosan yaitu $\leq 5 \%$. Rendahnya kadar nitrogen pada chitosan udang galah dipengaruhi oleh penggunaan konsentrasi $\mathrm{NaOH}$ dan proses deproteinase menyebabkan terjadinya kehilangan protein dalam jumlah banyak oleh reaksi antara protein dengan larutan pembentuk ester (Na-proteinat) (Nadia, 2014).

Konsentrasi $\mathrm{NaOH} 40$ - $50 \%$ dalam proses deasetilasi secara signifikan dapat meningkatkan kelarutan chitosan 93.19 - 95.80\%. Chitosan yang digunakan sebagai bahan baku pembuatan edible film mempunyai tingkat kelarutan yang tinggi (Purwanti dan Yusuf, 2013).

\section{Pengaruh Konsentrasi Penambahan Chitosan pada Edible Coating dan Lama Penyimpanan terhadap Susut Berat, Soluble Solid, Total Acidity dan Vitamin C Buah Tomat}

\section{Susut Berat}

Buah dan sayuran akan mengalami penurunan susut berat setelah proses pemanenan (pascapanen). Penelitian ini menggunakan tomat dengan kematangan rata, hasil analisis menunjukkan susut berat antara tomat kontrol dengan tomat menggunakan chitosan memiliki nilai susut berat yang berbeda. Gambar 1 menunjukkan penurunan susut berat tomat yang disimpan dapat dikendalikan oleh penggunaan chitosan.

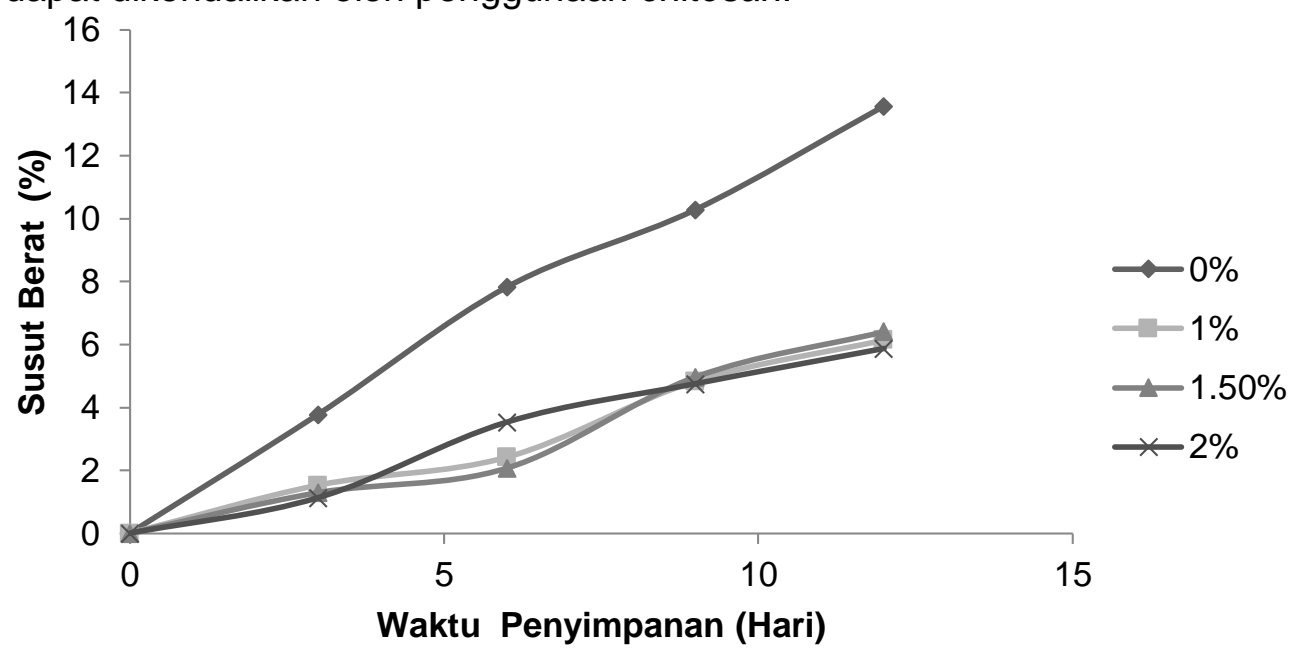

Gambar 1. Pengaruh Konsentrasi Chitosan dan Lama Penyimpanan terhadap Susut Berat Buah Tomat

Berdasarkan Gambar 1, terlihat susut berat tomat dipengaruhi oleh lama penyimpanan dan konsentrasi chitosan. Nilai susut berat tertinggi diperoleh pada buah chitosan $0 \%$, yaitu 
rata-rata $13.57 \%$ pada penyimpanan 12 hari, sedangkan tomat dengan menggunakan chitosan lebih dapat ditekan susut berat pada tomat dengan rata-rata $5.87 \%$ dengan konsentrasi chitosan $2 \%$ selama penyimpanan 12 hari. Setelah pascapanen proses respirasi dan transpirasi akan terus berlangsung menyebabkan peningkatan susut berat. Hilangnya air melalui pori-pori buah merupakan proses terjadinya transpirasi sehingga berat buah menurun. Keluarnya air dari dalam buah selama penyimpanan disebabkan proses pencelupan tomat dengan chitosan yang tidak merata sehingga permukaan kulit tomat tidak tertutupi secara maksimal (Najah, 2015).

Semakin tinggi konsentrasi chitosan menyebabkan stomata buah yang dilapisi chitosan lebih tertutup dibandingkan dengan perlakuan tanpa chitosan (Firmansyah, 2016). Kehilangan air karena proses transpirasi dapat dicegah dengan penggunaan chitosan dalam konsentrasi tinggi, maka susut berat akan menurun. Sebagian air dalam jaringan bahan akan menguap selama penyimpanan dan hal tersebut berdampak pada kehilangan susut berat, pelayuan dan mengkriputnya buah (Muchtadi dan Sugiyono (1992) dalam Firmansyah (2016).

Longgarnya ikatan sel dan besarnya ruang udara terlihat mengkeriput sebagai akibat dari terjadinya proses transpirasi menyebabkan tekanan dinding oleh isi sel dalam jumlah besar maka tekstur pada buah berubah (Suharjo dan Harini, 2005). Konsentrasi chitosan yang tinggi bisa mencegah proses respirasi dan transpirasi yang menurunkan (susut berat). Penyimpanan selama 12 hari untuk konsentrasi chitosan $2 \%$ memberikan susut berat yang paling rendah, sedangkan konsentrasi chitosan $0 \%$ memberikan susut berat paling tinggi.

Wahyudi (2018) menyatakan aktivitas antioksidan pada chitosan cukup tinggi dengan nilai $\mathrm{IC}_{50}$ tersebut memiliki arti sebanyak $20.42 \mathrm{mg}$ ekstrak chitosan mampu menghambat 50 $\%$ radikal bebas dari $0.078 \mathrm{mg} \mathrm{DPPH}$.

Hasil analisis ragam Anova RAK menggunakan SPSS 16.0, menunjukkan bahwa buah yang disimpan dalam waktu yang lama tidak memberikan dampak pada susut berat buah tomat dengan taraf signifikan $(>0.05)$ dan secara fisik belum mengalami kerusakan sampai penyimpanan 12 hari.

\section{Jumlah Soluble Solids}

Prinsip mengukur suatu soluble solids berdasarkan banyaknya bahan yang akan dilarutkan dalam air. Jumlah soluble solids dalam suatu larutan dapat diukur dengan menggunakan metode jumlah soluble solids (Tyanjani dan Yunianta, 2015). Indikator tingginya jumlah soluble solids pada suatu bahan pangan dapat dilihat berdasarkan jumlah dari kandungan glukosa dan fruktosa pada bahan tersebut. Anggraini dan Widjanarko (2018), menyatakan bahwa tingkat kematangan pada buah memiliki hubungan dengan jumlah soluble solids. Gambar 2 menunjukkan buah tomat dengan perlakuan chitosan dan lama penyimpanan diperoleh jumlah soluble solids tertinggi pada chitosan $2 \%$, penyimpanan hari ke-3.

Berdasarkan hitungan Anova penggunaan chitosan tidak memberikan pengaruh pada jumlah soluble solids ( $p>0.05$ ). Tomat dengan waktu simpan 0 sampai 9 hari dan konsentrasi chitosan masing-masing $1 \%, 1.5 \%$ dan $2 \%$ menunjukkan jumlah soluble solids cenderung meningkat, namun hari ke 12 penyimpanan terjadi penurunan soluble solids. Sedangkan, pada tomat tanpa menggunakan chitosan (kontrol) mengalami penurunan nilai soluble solids dibandingkan dengan buah yang menggunakan chitosan. Hasil analisis dissolved solids menunjukkan bahwa chitosan dapat menurunkan soluble solids dan mengurangi laju respirasi pada penyimpanan tomat. Novita (2012) menyatakan bahwa selama penyimpanan tomat akan mengalami penurunan jumlah soluble solids, diduga karena gula pereduksi terurai menjadi asam piruvat oleh proses respirasi yang menghasilkan $\mathrm{CO}_{2}$ dan $\mathrm{H}_{2} \mathrm{O}$. 


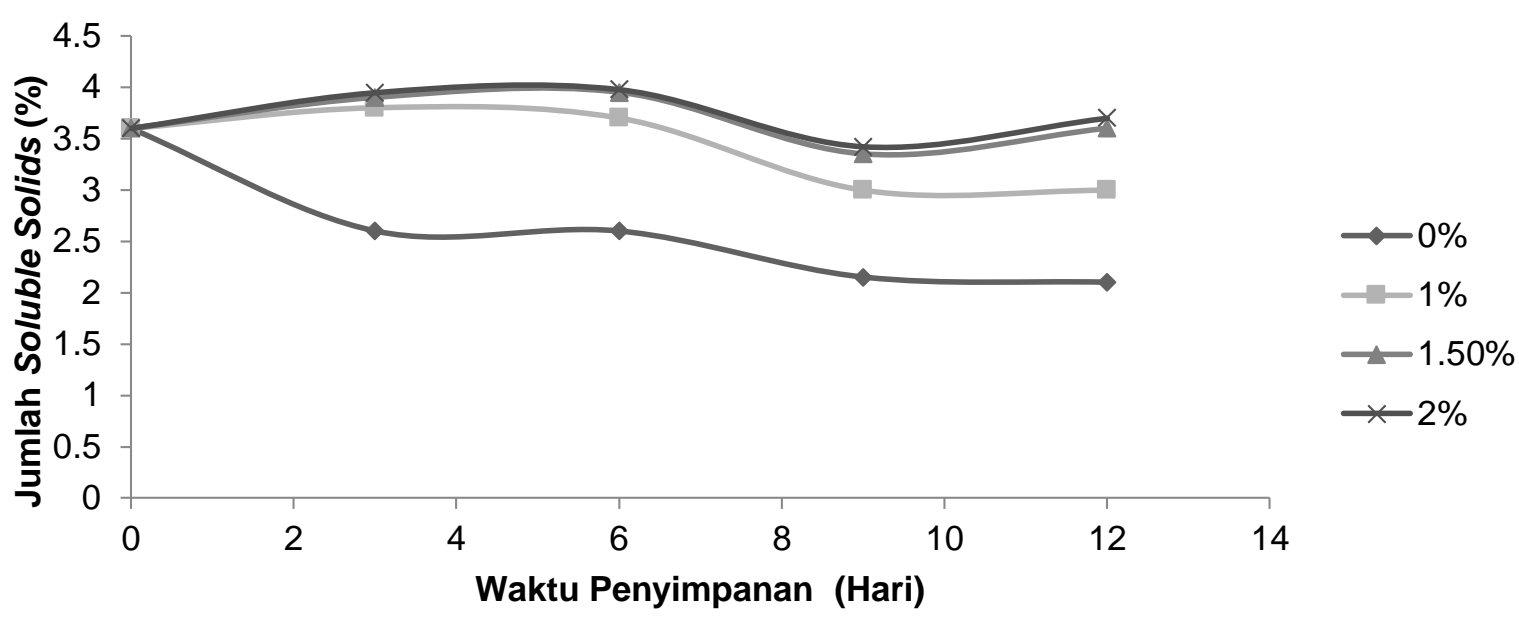

Gambar 2. Jumlah Soluble Solids Tomat

Cha and Chinnan (2010) menyatakan bahwa polisakarida memungkinkan dalam pembentukan permeabilitas yang menghambat respirasi karena membatasi ketersediaan $\mathrm{O}_{2}$. Menurut Ikhsan (2014), terbatasnya umur simpan buah-buahan disebabkan karena pada buah masih mengalami proses respirasi yang mendorong buah cepat matang sampai lewat matang. Terjadi kenaikan sampai penurunan intensitas kerusakan tomat selama penyimpanan. Serangan mikroorganisme dan sifat fisiologis yang menurun menyebabkan terjadinya perubahan pada tingkat kerusakan selama penyimpanan (Andriani, 2018).

Selama proses pematangan buah dan sayur terjadi perubahan kandungan karbohidrat dan gula hal ini dikarenakan buah dan sayuran yang disimpan masih melakukan aktivitas pada sisa hidupnya sehingga persediaan karbohidrat digunakan sebagai sumber energi Winarno dan Wirakartakusumah (1981) dalam Arrahma (2010).

Tomat yang disimpan selama 7 hari, jumlah soluble solids lebih meningkat, namun terjadi penurunan pada hari ke-12. Tomat mengandung soluble solids dalam jumlah banyak yang berbentuk gula. Kandungan gula pada tomat matang akan meningkat, diiringi dengan terjadinya penurunan jumlah asam-asam organik pada tomat. Hal tersebut sesuai dengan pernyataan Novita (2012), bahwa selama proses pematangan terjadi peningkatan kandungan gula pada tomat, diduga penguraian pati dalam bentuk glukosa dan fruktosa. Aktivitas enzim pada tomat yang lewat masak akan menurun menyebabkan jumlah soluble solids (Arrahma, 2010).

\section{Total Acidity}

Hasil analisis menunjukkan pada penyimpanan hari ke-0, konsentrasi chitosan $0-2 \%$ diperoleh nilai total acidity tertinggi yang dapat dilihat pada Gambar 3. Hasil analisis total acidity pada beberapa konsentrasi chitosan dan lama penyimpanan berkisar $0.82-0.66 \%$, sedangkan tomat tanpa penggunaan chitosan dengan lama penyimpanan 12 hari berkisar $0.06 \%$. Gambar 3, menujukkan bahwa penggunaan chitosan dapat menekan terjadi penurunan total acidity, sedangkan tomat tanpa penggunaan chitosan nilai total acidity menurun secara drastis. Tomat pada awal panen (tomat tua/ mature) mengandung asamasam organik yang cukup tinggi, sedangkan pada proses pematangan (ripening) selanjutnya tidak terdapat peningkatan yang berarti pada nilai total acidity tersebut dan mengalami penurunan pada tomat yang menuju busuk. Helyes dan Lugas (2006) dan Bari et al. (2006), diduga substrat dari asam-asam organik digunakan sebagai energi saat respirasi sehingga total acidity pada buah menurun selama buah disimpan. Penurunan jumlah asam-asam organik diikuti oleh menurunnya nilai total acidity pada buah. Hal tersebut terjadi pada semua buah klimaterik, dimana penyimpanan menyebabkan asam-asam organik berkurang dengan sangat cepat pada buah karena dimanfaatkan sebagai substrat sumber energi pada proses respirasi, bersamaan dengan penurunan total acidity (Hofman et al, 1997 dan Baldwin,1999). 


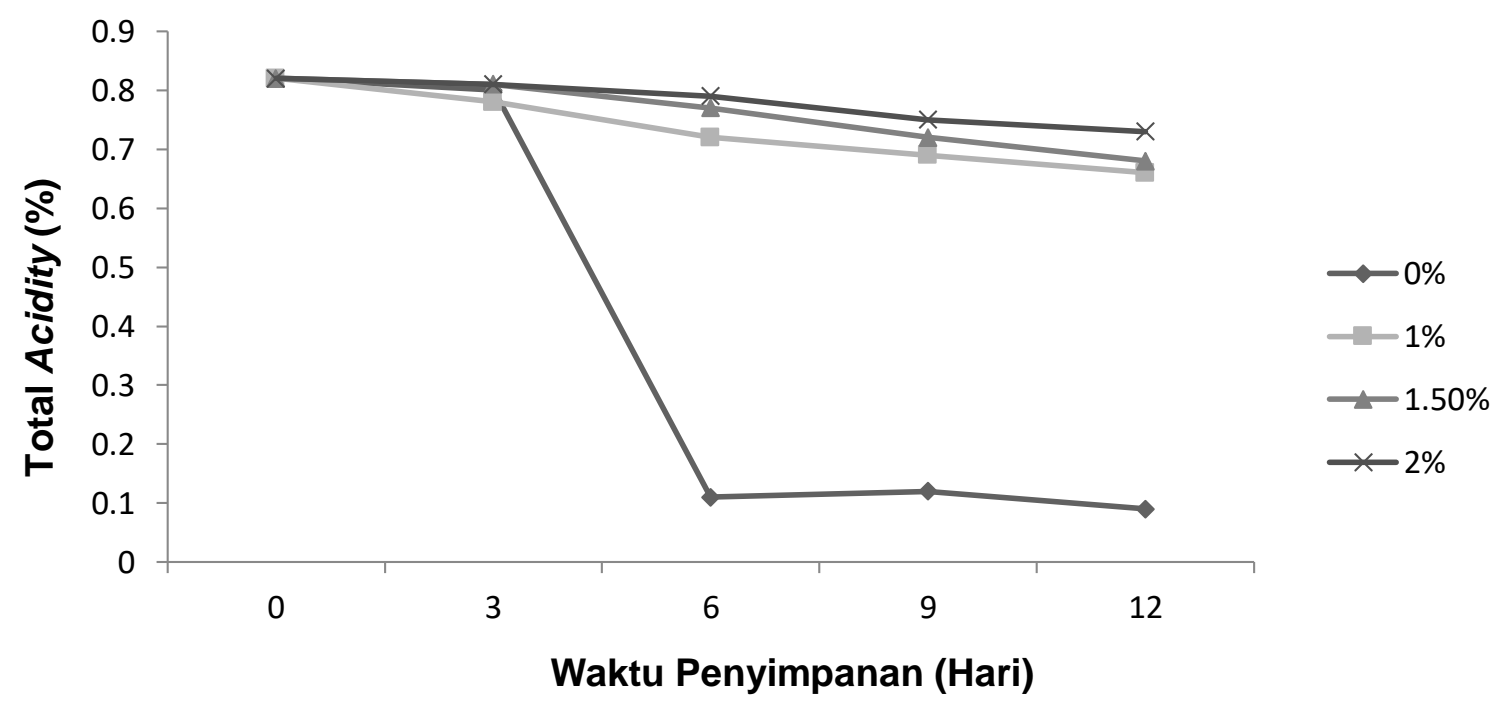

Gambar 3. Total Acidity Tomat

\section{Vitamin C}

Vitamin C mempunyai nama kimia asam askorbat yang merupakan vitamin yang mudah larut dalam air. Sayur-sayuran dan buah-buahan yang segar merupakan sumber vitamin $\mathrm{C}$. Berdasarkan sifat dasarnya, vitamin $\mathrm{C}$ termasuk vitamin yang mudah mengalami kerusakan. Sumardiono et al (2009), menyatakan peningkatan suhu berhubungan dengan laju oksidasi vitamin $\mathrm{C}$ yang cepat, dimana pada suhu $90^{\circ} \mathrm{C}$ dalam waktu 10 jam menyebabkan $\pm 95 \%$ vitamin $C$ mengalami kerusakan. Sesuai pendapat tersebut, Nunes dan Emond (2003) mengemukakan suhu, cahaya dan udara selama penyimpanan dapat berpengaruh terhadap reaksi oksidasi vitamin C. Umumnya bahan pangan yang disimpan pada suhu tinggi dengan waktu penyimpanan yang lama akan menyebabkan penurunan kadar vitamin C. Gambar 4 menunjukkan rerata hasil analisis vitamin C.

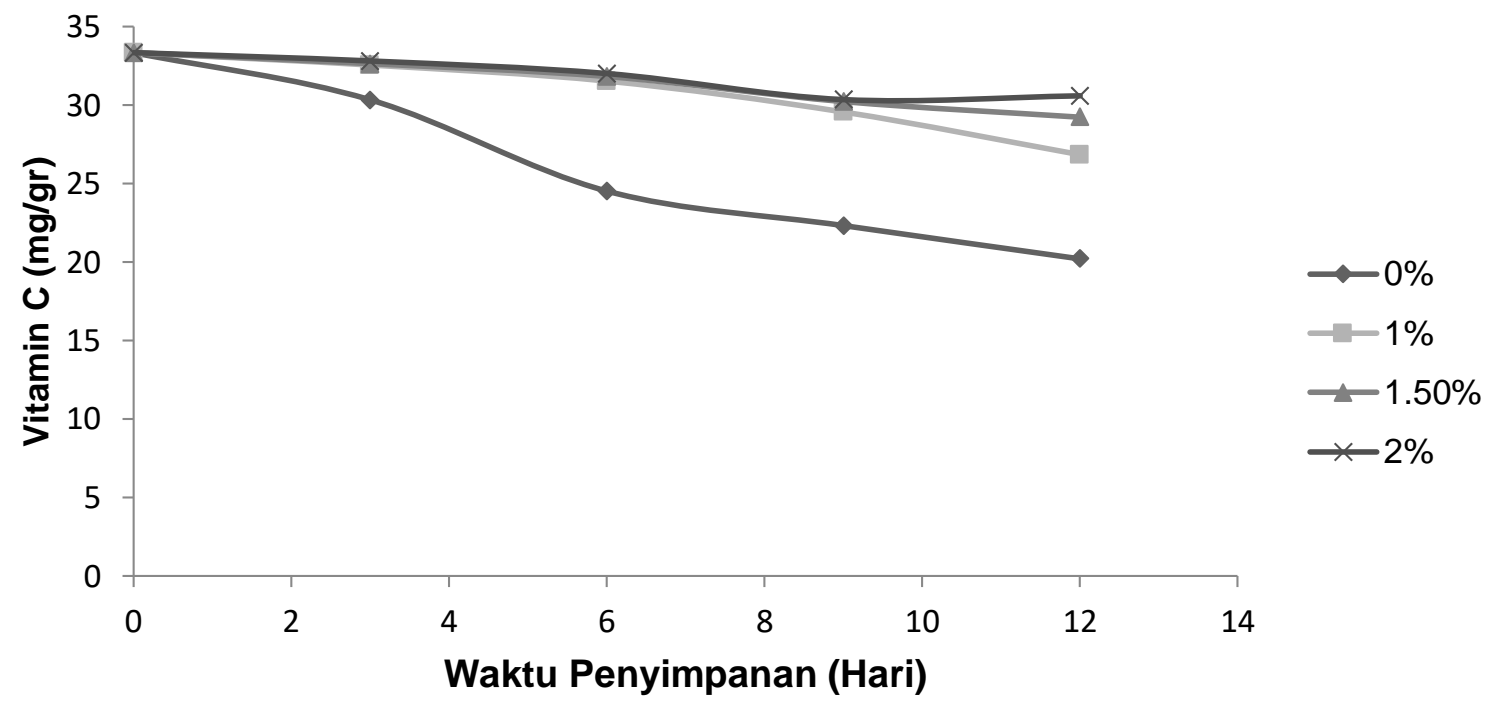

Gambar 4. Vitamin C

Hasil analisis menunjukkan nilai vitamin $\mathrm{C}$ pada buah tomat dengan pemberian beberapa konsentrasi chitosan masing-masing sebesar $1 \%, 1.5 \%$ dan $2 \%$ memiliki rerata 
berkisar 33.32-26.82 $\mathrm{mg} / 100 \mathrm{~g}$ bahan. Sedangkan, tomat tanpa perlakuan (kontrol) yaitu chitosan $0 \%$ memiliki rerata nilai vitamin C $33.32-20.19 \mathrm{mg} / 100 \mathrm{~g}$. Penurunan nilai vitamin $\mathrm{C}$ lebih rendah pada tomat yang menggunakan chitosan, hal ini diduga chitosan dapat menurunkan terjadinya reaksi oksidasi sehingga vitamin $\mathrm{C}$ dapat dipertahankan selama penyimpanan. Hal ini sesuai dengan pernyataan Winarno (2002), reaksi oksidasi menyebabkan kerusakan vitamin $\mathrm{C}$ dan vitamin $\mathrm{C}$ juga bersifat mudah terlarut dalam air.

\section{SIMPULAN}

Berdasarkan hasil analisis chitosan maka diperoleh $7.90 \%$ kadar air, 3.72\% kadar abu dan $4.01 \%$ kadar protein. Hasil penelitian menunjukkan chitosan berpengaruh terhadap vitamin $\mathrm{C}$, total acidity, jumlah soluble solids dan susut berat pada tomat yang disimpan.

\section{UCAPAN TERIMA KASIH}

Terimakasih pada Politeknik Negeri Ketapang, Jurusan Teknologi Hasil Pengolahan yang telah meminjamkan Laboratorium penelitian ini dan P3KM yang telah memberikan dana penelitian tersebut.

\section{DAFTAR PUSTAKA}

Agustina, S., Swantara,I.M.D., Suartha, I.N. 2015. Isolasi Kitin, Karakterisasi dan Sintesis Chitosan Dari Kulit Udang. Program Magister Kimia Terapan. Universitas Udayana. Bali.

Anggraini, F.S dan Widjanarko, B.S. 2018. Pengaruh Penambahan Ekstrak Bekatul Terhadap Aktivitas Antioksidan, Total Fenol Dan Kadar Flavonoid Minuman Fungsional Sari jagung-Ekstrak Bekatul. Jurnal Pangan dan Agroindustri 6:1, 53-63

Arrahma R, 2010. Perlakuan Pendahuluan Buah Tomat (Lycopersicum esculentum mill) segar untuk transportasi jarak jauh. Departemen Teknologi Industri Pertanian. Fakultas Teknologi Pertanian. Institut Pertanian Bogor. Bogor.

Andriani. S.E, Nurwantoro, Hintono. A, 2018. Perubahan Fisik Tomat Selama Penyimpanan Pada Suhu Ruang Akibat Pelapisan Dengan Agar-Agar. Program Studi Teknologi Pangan. Fakultas Peternakan dan Pertanian. Universitas Diponegoro. Semarang.

Baldwin, E.A. 1999. Edible coatings for fresh fruits and vegetables: past, present and future. Dalam : Krochta J.M, Baldwin E.A, Nisperos-Carriedo MO, eds. Edibles coatings and films to improve food quality. Lancaster. Technomic Pub. CO. Inc.

Bari, L. P., Hasan, N., Absar, M.E., Haque, M.I.I.E. Khuda, M.M. Pervin, S. Khatun, dan M.I. Hossain. 2006. Nutritional Analysis of Local Varieties of Papaya (Carica papaya L.) at Different Maturation Stages. Pakistan J. Biol. Sci. 9:137- 140.

Bastaman S. 1989. Studies On Degradation and Extraction of Chitin and Chitosan From Prawn Shells. Belfast: The Departement Of Mechanical Manufacturing , Aeronautical and Chemical Engineering. The Queen's University.

Cha, D. S and Chinnan, M., S. 2010. Biopolymer-based antimicrobial packaging: A Review. Critical Reviews in Food Sci. and Nutrit. 44(4) : 223-237

Firmasyah, Y. Efendi, $R$ dan Rahmayuni. 2016. Pemanfaatan Chitosan Untuk Memperpanjang Umur Simpan Buah Pepaya Varietas California. Program Studi Teknologi Hasil Pertanian. Jurusan Teknologi Pertanian. Fakultas Pertanian. Universitas Riau. Pekanbaru.

Hardjito, L. 2006. Aplikasi Chitosan Sebagai Bahan Tambahan Makanan dan Pengawet. Prosiding Seminar Nasional Kitin-Chitosan. Departemen Teknologi Hasil Perairan. FPIK IPB, Bogor.

Helyes, L. Z dan Lugasi, A. 2006. Tomato Fruit Quality and Content Depend on Stage of Maturity. Hort Sience. 41:1400-1401. 
Hofman, P.J., Smith, L.G., Joyce, D.C dan Johnson,G.I.1997. Bagging of Mango (Mangifera indica cv Keitt) Fruit Influence Fruit Quality and Mineral Composition. Postharvest Biol. And Technol. 12 :285-292.

Hobson, G.E., Davies, J.N. 1971. The Tomato.Di dalam: Hulme AC (eds) The Biochemsitry of Fruit and Product. Vol II. Academic Press. London. Karp G. 2000. Cell Biology . Ed ke-2. University of Florida.

Hossain, M.S dan lqbal, A. 2014. Production and characterization of chitosan from shrimp waste. Journal Bangladesh Agril Univ 12(1): 153-160

Ikhsan, M.A., Tamrin dan Kadir, Z.M. 2014. Pengaruh Media Simpan Pasir dan Biji Plastik Dengan pemberian Air Pendingin Terhadap Perubahan Mutu Pada Buah Pisang Kepok (Musa Nurmalis L). Jurusan Teknik Pertanian. Fakultas Pertanian. Universitas Lampung. Lampung.

Islama. M., Masum. S., Rahmana. M.M., Molab. A.I., Shaikh. A.A., Roya. S.K. 2011. Preparation of chitosan from shrimp shell and investigation of its properties. Journal of Basic and Applied Sciences 11(1): 1-10.

Khan, T.A., Peh, K. K dan Chang, H. S. 2002. Reporting Degree of Deacetylation Value of Chitosan; the Influence of Analytical Methods, J Pharm Sci, 5 (3) : 205-212.

Kumari, S., Rath, P., Kumar, S.H. 2016. Chitosan from shrimp shell (Crangon crangon) and fish scales (Labeorohita): Extraction and characterization. African

Linawati H. 2006. Chitosan Bahan Alami Pengganti Formalin. Departemen Teknologi Perairan (THP) Fakultas Perikanan dan IImu Kelautan. Institut Pertanian Bogor (FKIK-IPB). Bogor.

Muchtadi, T.R dan Sugiyono. 1992. Ilmu Pengetahuan Bahan Pangan. Pusat Antar Universitas Pangan dan Gizi IPB, Bogor.

Mursida, Tasir dan Sahriawati., 2018. Efektifitas Larutan Alkali Pada Proses Deasetilasi Dari Berbagai Bahan Baku Chitosan. Program Studi Teknologi Pengolahan Hasil perikanan. Jurusan Teknologi hasil Perikanan. Politeknik Pertanian Negeri Pangkep. Sulawesi Selatan.

Nadia. H.M.L., Suptijah. P dan Ibrahim. B, 2014. Produksi dan Karakterisasi Nano Chitosan dari Cangkang Udang Windu dengan Metode Gelasi lonik. Jurnal Pengolahan Hasil Perikanan Indonesia 17(2): 119-126.

Nadia, H.M.L., Huli, O. L dan Nadia, R.A. L, 2018. Pembuatan dan Karakterisasi Chitosan dari Cangkang Rajungan (Portunus Pelagicus) Asal Sulawesi Tenggara. Jurusan Teknologi Hasil Perikanan. Fakultas Perikanan dan IImu Kelautan. Universitas Halu Oleo. Kendari. Sulawesi Tenggara.

Najah, K. Basuki, E dan Alamsyah, A. 2015. Pengaruh Konsentrasi Chitosan Terhadap Sifat Fisik Dan Kimia Buah Tomat Selama Penyimpanan. Program Studi Ilmu Dan Teknologi Pangan. Fakultas Teknologi Pangan dan Agroindustri. Universitas Mataram. Mataram.

Nunes, M.C.D dan Emond, J. P. 2003. Storage Temperature. dalam : Bart, J.A dan Brecht, J.K (ed). Postharvest Physiology and Pathology of Vegetables : Second Edition. Marcel Dekker Inc, Quebec.

Novita. M, Satriana, Martunis, Rohaya. S, dan Hasmarita. E, 2012. Pengaruh Pelapisan Chitosan Terhadap Sifat Fisik dan Kimia Tomat Segar (Lycopersicum Pyriforme) Pada Berbagai Tingkat Kematangan. Jurusan Teknologi Hasil Pertanian. Fakultas Pertanian. Universitas Syiah Kuala. Darussalam. Banda Aceh.

Purwanti, A dan Yusuf, M. 2013. Upaya Peningkatan Kelarutan Chitosan dalam Asam Asetat dengan Melakukan Perlakuan Awal pada Pengolahan Limbah Kulit Udang menjadi Chitosan. Jurusan Teknik Kimia. Fakultas Teknologi Industri. Institut Sains dan Teknologi AKPRIND. Yogyakarta.

Ploydee, E., Chaiyanan, S. 2014. Production of High Viscosit y Chitosan from Biologicall y Purified Chitin I solated by Microbial Fermentation and Deproteinization. International Journal of Polymer Science 9(3):146-162. 
Rachmania, D. 2011. Karakteristik Nano Chitosan Cangkang Udang Vannamei (Litopenaeus vannamei) Dengan Metode Gelasi lonik. Departemen Teknologi Hasil Perairan. Fakultas Perikanan dan Ilmu Kelautan. Institut Pertanian Bogor. Bogor.

Rachmawati, M. 2010. Pelapisan Chitosan Pada Buah Salak Pondoh (Salacca edulis Reinw) Sebagai Upaya Memperpanjang Umur Simpan Dan Kajian Sifat Fisiknya Selama Penyimpanan. Jurusan Teknologi Hasil Pertanian. Fakultas Pertanian. Universitas Mulawarman. Samarinda.

Rahmawati, W. Herasari, D dan Husniati. 2012. Produksi Chitosan Dari Bahan Baku Cangkang Menggunakan Metode Kimia dan Enzimatis Dengan Enzim Kitin Deasetilase. Jurusan Kimia. Fakultas Matematika dan Ilmu Pengetahuan Alam. Universitas Lampung. Lampung.

Rusmanto, E.A., Rahim dan Hutomo, G.S. 2017. Karakteristik Fisik dan Kimia Buah Tomat Hasil Pelapisan Dengan Pati Talas. Program Studi Agroteknologi Fakultas Pertanian. Universitas Tadulako. Palu

Rochima, E. 2007. Karakterisasi Kitin Dan Chitosan Asal Limbah Rajungan Cirebon Jawa Barat. Fakultas Perikanan dan Ilmu Kelautan. Universitas Padjadjaran. Bandung.

Sumardiono, S., Basri, M dan Sihombing, P.R. 2009. Analisis Sifat-Sifat Psiko-kimia Buah Tomat (Lycopersicon Esculentum) Jenis Tomat Apel, Guna Peningkatan Nilai Fungsi Buah Tomat Sebagai Komoditi Pangan Lokal. Jurusan Teknik Kimia. Fakultas Teknik. Universitas Diponegoro. Semarang.

Suharjo dan Harini, N. 2005. Ekstraksi chitosan dari cangkang udang windu (Penaeus monodon sp.) secara fisika-kimia (kajian berdasarkan ukuran partikel, tepung chitin dan konsentrasi $\mathrm{NaOH}$ ). Gamma.1(1): 7-15.

Suptijah, P., Jacoeb, M.A., Rachmania, D. 2011. Karakterisasi nano chitosan cangkang udang vannamei (Litopenaeus vannamei) Dengan Metode Gelasi lonik. Departemen Teknologi Hasil Perairan. Fakultas Perikanan dan IImu Kelautan. Institut Pertanian Bogor. Bogor.

Sitorus, R. F., T. K. Karo dan Z. Lubis. 2014.Pengaruh Konsentrasi Chitosan Sebagai Edible Coating dan Lama Penyimpanan Terhadap Mutu Buah Jambu Biji Merah.Jurnal Rekayasa Pangan dan Pertanian, volume 2(1): 1-10.

Trisnawati, E., Andesti, D dan Saleh, A. 2013. Pembuatan Chitosan dari Limbah Cangkang Kepiting sebagai Bahan Pengawet Buah Duku dengan Variasi Lama Pengawetan. Jurusan Teknik Kimia. Fakultas Teknik. Universitas Sriwijaya. Palembang.

Tyanjani, F.E dan Yunianta. 2015. Pembuatan Dekstrin Dari Pati Sagu (Metroxylon Sagus Rottb) Dengan Enzim B-Amylase Terhadap Sifat Fisiko Kimia. Jurnal Pangan dan Agroindustri 3:3, 1119-1127

Wahyudi, C.T., Wijayanti, D.S dan Harijono. 2018. Pengaruh Konsentrasi Media Penyalut dan Lama Ultrasonikasi Terhadap Ukuran Partikel dan Aktivitas Antioksidan Nano Ekstrak Bawang Putih Tunggal (Allium sativum L). Jurusan Teknologi hasil Pertanian. Fakultas Teknologi Pertanian. Universitas Brawijaya. Malang

Widodo, A., Mardiah, dan Prasetyo, A. 2005. Potensi Chitosan dari Sisa Udang sebagai Koagulan Logam Berat Limbah Cair Industri. Jurusan Teknik Kimia Institut Teknologi Sepuluh November. Surabaya.

Winarno, F.G dan Wirakartakusumah, M.A. 1981. Fisiologi Lepas Panen. PT Sastra Hudaya. Jakarta.

Winarno, F.G. 2002. Fisiologi Lepas Panen Produk Hortikultura. M-Brio Press, Bogor. 